\title{
PKM PELATIHAN PENULISAN KARYA ILMIAH BAGI PELAJAR SMK DI KABUPATEN SIMALUNGUN DAN KOTA PEMATANGSIANTAR
}

\author{
Writing on Scientific Works for Vocational School Students in Simalungun District and \\ Pematangsiantar City
}

\author{
Anjar Wanto ${ }^{1 *}$ \\ Muhammad Ridwan Lubis ${ }^{2}$ \\ lin Parlina ${ }^{3}$ \\ *ISTIKOM Tunas Bangsa, \\ Pematangsiantar, Sumatera Utara, \\ Indonesia \\ 2AMIK Tunas Bangsa, Pematangsiantar, \\ Sumatera Utara, Indonesia \\ 3AMIK Tunas Bangsa, Pematangsiantar, \\ Sumatera Utara, Indonesia \\ *email: \\ anjarwanto@amiktunasbangsa.ac.id
}

\begin{abstract}
Abstrak
Pelatihan ini bertujuan untuk menumbuhkan dan meningkatkan minat menulis, khususnya menulis karya ilmiah bagi pelajar SMK di kabupaten Simalungun dan Kota Pematangsiantar. Pengabdian ini dilaksanakan di 2 Sekolah SMK yang berbeda yang merupakan Mitra dari tim pengabdian, Mitra I adalah SMK Swasta Anak Bangsa yang terletak di Kabupaten Simalungun dan SMK Swasta Teladan yang terletak di Kota Pematangsiantar. Kegiatan dilaksanakan selama 4 hari selama bulan Juli 2019, Pada SMK Swasta Anak Bangsa Kegiatan dilaksanakan pada hari Sabtu dan Minggu tanggal 6-7 juli 2019, mulai pukul 08.00-I7.00 WIB dengan peserta sebanyak 52 siswa, Sedangkan pada SMK Swasta Teladan dilaksanakan pada tanggal 13-14 Juli 2019 di pukul yang sama, dengan peserta sebanyak 25 siswa. Sasaran kegiatan ini adalah para pelajar SMK di Kabupaten Simalungun (SMK Anak Bangsa) dan Kota Pematangsiantar (SMK Teladan). Alasan pemilihan lokasi pengabdian adalah karena kurangnya minat pelajar di sekolah-sekolah tersebut dalam hal menulis karya ilmiah, serta minimnya karya tulis ilmiah yang dihasilkan. Kegiatan ini menggunakan metode presentasi/ceramah, diskusi, tanya jawab, dan praktik/latihan. Hasil dari kegiatan pengabdian ini menunjukkan bahwa dari 52 peserta siswa di SMK Swasta Anak Bangsa, 25 siswa mampu menjawab soal (Post Test) dengan benar sebanyak 10 soal (48\%) dimana sebelumnya hanya mampu menjawab soal (Pre Test) dengan benar 9 soal sebanyak 8 peserta (I5\%). Sedangkan dari 25 peserta siswa di SMK Swasta Teladan, 12 siswa mampu menjawab soal (Post Test) dengan benar sebanyak 10 soal (48\%) dimana sebelumnya hanya mampu menjawab soal (Pre Test) dengan benar 9 soal sebanyak 2 peserta (8\%).
\end{abstract}

Kata Kunci:

Pelatihan

Penulisan

Karya Ilmiah

Pelajar

Publikasi

\section{Keywords:}

Training

Writing

Scientific work

Student

Publication

\begin{abstract}
This training aims to foster and increase interest in writing, especially writing scientific papers for vocational students in Simalungun Regency and Pematangsiantar City. This dedication is carried out in 2 different Vocational Schools which are Partners of the dedication team, Partner $I$ is the National Children's Vocational School located in Simalungun district and an exemplary Private Vocational School located in Pematangsiantar City. The activity was held for 4 days during July 2019, at the National Private Vocational School. The activity was carried out on Saturday and Sunday 6-7 July 2019, starting at 08.00-17.00 WIB with 52 students participating, while the Exemplary Private Vocational School was held on the 13th - I July 2019 at the same time, with 25 students. The targets of this activity are vocational students in Simalungun District (SMK Anak Bangsa) and Pematangsiantar City (Exemplary SMK). The reason for the selection of service locations is because of the lack of student interest in these schools in terms of writing scientific papers, as well as the lack of scientific papers produced. This activity uses the method of presentation / lecture, discussion, question and answer, and practice / practice. The results of this community service activity show that out of 52 student participants in the Vocational School Private Nation, 25 students were able to answer the questions (Post Test) correctly as many as 10 questions (48\%) where previously only able to answer the questions (Pre Test) correctly 9 questions as many as 8 participants (15\%). While from 25 student participants in Exemplary Private Vocational Schools, 12 students were able to answer questions (Post Test) correctly as many as 10 questions (48\%) where previously only able to answer questions (Pre Test) correctly 9 questions as many as 2 participants (8\%).
\end{abstract}




\section{PENDAHULUAN}

Penguasaan dan pemahaman Ilmu Pengetahuan, Teknologi, dan Seni (IPTEKS) bagi pelajar adalah hal yang sangat penting. Penguasaan IPTEKS yang mumpuni akan meningkatkan kualitas sumber daya manusia yang berdaya saing tinggi. Upaya penguasaan tersebut dapat dilakukan melalui pendidikan, baik yang bersifat formal maupun nonformal (Casmudi \& Ryan Angga Pratama, 2019). Karena Salah satu penentu kualitas bangsa adalah pendidikan. Semakin bagus pendidikan yang dimiliki oleh suatu bangsa, maka semakin berkualitas pula bangsa tersebut. Oleh karena itu, setiap bangsa selalu berusaha meningkatkan mutu pendidikannya (S. Sumartini, Mulyani, \& Nugroho, 2019). Dalam rangka meningkatkan kualitas pendidikan, khususnya di Kabupaten Simalungun dan Kota Pematangsiantar, berbagai program peningkatan kualitas pelajar telah banyak dilakukan baik oleh pemerintah maupun perguruan tinggi melalui program pengabdian kepada masyarakat. Akan tetapi belum pernah sekalipun adanya pelatihan tentang penulisan karya ilmiah, khususnya pada SMK Swasta Anak Bangsa di Kabupaten Simalungun dan SMK Swasta Teladan di Kota Pematangsiantar. Hal ini diketahui setelah pihak tim pengabdian melakukan pembicaraan dengan Kepala Sekolah dari masing-masing sekolah. Padahal Karya tulis ilmiah memiliki peranan yang sangat penting dalam meningkatkan mutu dan penyebaran keilmuan.

Karya ilmiah merupakan karya tulis yang dibuat untuk dimuat atau diterbitkan kedalam jurnal maupun kumpulan artikel yang ditulis secara ilmiah serta mengikuti pedoman maupun kaidah ilmiah yang telah disepakati. Penulisan artikel nantinya akan mengikuti struktur sajian tulisan secara sistematis, maupun ketentuan serta etika penulisan yang berpedoman terhadap pola penulisan karya ilmiah. Untuk memperkuat argumen dalam artikel, biasanya digunakan dasar teoritis, ketentuan atau kebijakan, fakta atau logika umum (Syamsul Alam, 20I5). Karya tulis ilmiah memiliki peranan yang sangat penting dalam meningkatkan mutu dan penyebaran keilmuan. Tidak hanya pada perguruan tinggi, karya tulis ilmiah juga sangat dibutuhkan bagi pelajar di sekolah-sekolah menengah, khususnya sekolah kejuruan di Indonesia. Melalui karya tulis ilmiah, sebuah bidang ilmu dapat terus ditingkatkan dan diperbaharui. Lewat karya tulis ilmiah pula, temuan-temuan maupun hal-hal baru dapat dituangkan melalui jurnal dan tulisan-tulisan (Kumalasari, Rokhman, \& Zulkarnain, 20I5).

Karya tulis ilmiah juga mampu meningkatkan Sumber daya Manusia dari pelajar itu sendiri dalam mengarungi persaingan di era globalisasi serta menyongsong masa depan yang cerah. Akan tetapi sangat kurangnya minat pelajar di sekolah-sekolah dalam hal menulis karya ilmiah serta belum pernah sekalipun adanya pelatihan tentang penulisan karya ilmiah, khususnya pada SMK Swasta Anak Bangsa di Kabupaten Simalungun maupun SMK Swasta Teladan Kota Pematangsiantar serta minimnya hasil karya tulis ilmiah pelajar di sekolah-sekolah tersebut, menjadi salah satu yang melatar belakangi mengapa perlu diadakannya kegiatan pelatihan penulisan karya ilmiah ini, selain itu ketua tim PKM juga pernah melakukan pengabdian sebelumnya di SMK Swasta Anak Bangsa (Wanto, Suhendro, \& Windarto, 2018), sehingga sedikit banyak nya mengetahui pelatihan apa yang dibutuhkan di sekolah tersebut. Akan tetapi hal ini bukan semata-mata kesalahan para pelajar, tetapi ada faktor-faktor lain yang mempengaruhi pelajar sehingga tidak mampu memaksimalkan kemampuannya dalam membuat karya ilmiah remaja. Salah satu nya seperti kurang nya pelatihan-pelatihan dalam pembuatan karya ilmiah sehingga membuat pelajar bingung mau memulai darimana, kurang nya dukungan dari guru dan sekolah hingga kurang nya motivasi terhadap para pelajar. Untuk mampu menumbuhkan minat dan ketrampilan menulis pelajar, maka perlu dilakukan kegiatan pelatihan penulisan karya ilmiah, sehingga nantinya setiap pelajar mampu memahami sistematika dan teknik penulisan karya ilmiah yang baik dan benar yang 
tersusun secara sistematis, logis, dan cermat termasuk dari segi bahasa. Diharapkan dari pelatihan ini juga akan menumbuhkan ide maupun gagasan yang akan dituangkan kedalam tulisan karya ilmiah. Karena hal ini tanpa disadari mampu meningkatkan sumber daya manusia dari pelajar itu sendiri (Marlene, Dwijayanti, Patrikha, \& Parjono, 2017). Secara umum pelatihan yang akan dilakukan meliputi : Pelatihan untuk penentuan permasalahan, penentuan metode yang digunakan, serta pembuatan proposal karya ilmiah secara keseluruhan, pelatihan pemanfaatan internet untuk membuat tulisan maupun penggalian sumber pustaka dan data, pelatihan pembuatan kutipan (citasi) tulisan, hingga pelatihan pembuatan laporan penulisan karya ilmiah.

Oleh karena itu, melalui pelatihan penulisan karya ilmiah ini diharapkan dapat meningkatkan dan menumbuhkan minat menulis dari para pelajar di sekolah-sekolah yang berada di Kabupaten Simalungun dan Kota pematangsiantar, khususnya pada SMK Swasta Anak Bangsa dan SMK Swasta Teladan, sehingga nantinya mereka mampu membuat karya ilmiah yang baik dan berkualitas.

\section{METODOLOGI}

Pelaksanaan PKM Pelatihan Penulisan Karya IImiah ini dilaksanakan di 2 Sekolah SMK yang berbeda yang merupakan Mitra dari tim pengabdian, Mitra I adalah SMK Swasta Anak Bangsa yang terletak di Kabupaten Simalungun dan Mitra 2 adalah SMK Swasta Teladan yang terletak di Kota Pematangsiantar. Kegiatan dilaksanakan selama 4 hari selama bulan Juli 2019. Pada SMK Swasta Anak Bangsa Kegiatan dilaksanakan pada hari Sabtu dan Minggu tanggal 6-7 juli 2019, mulai pukul 08.00-17.00 WIB dengan peserta sebanyak 52 siswa. Sedangkan pada SMK Swasta Teladan kegiatan ini dilaksanakan pada hari Sabtu dan Minggu tanggal 13-14 Juli 2019 pukul 08.00-17.00 WIB, dengan peserta sebanyak 25 siswa. Sasaran kegiatan ini adalah para pelajar SMK di Kabupaten Simalungun
(SMK Anak Bangsa) dan Kota Pematangsiantar (SMK Teladan). Alasan pemilihan lokasi pengabdian adalah karena kurangnya minat pelajar di sekolah-sekolah tersebut dalam hal menulis karya ilmiah, serta minimnya karya tulis ilmiah yang dihasilkan. Kegiatan ini menggunakan metode presentasi/ceramah, diskusi, tanya jawab, dan praktik/latihan. Penjelasan lengkap dari Metode yang digunakan dalam kegiatan pelatihan pembuatan karya ilmiah ini adalah sebagai berikut :

\section{Ceramah}

Materi yang diberikan adalah penjelasan tentang motivasi untuk menulis karya ilmiah, etika penulisan ilmiah, teknik penulisan karya ilmiah, kebahasaan dalam ragam karya ilmiah, penelusuran referensi melalui internet, penyusunan karya ilmiah, dan teknik swasunting disertai pemberian modul kepada masing-masing pelajar tentang tatacara dan trik penulisan karya ilmiah.

2. Diskusi dan Tanya Jawab

Pada tiap materi yang diberikan dan disampaikan, peserta dapat berdialog, berdiskusi dan melakukan tanya jawab dengan tim pengabdian.

3. Praktek Menulis

Para siswa diminta untuk melakukan praktek/latihan menulis. Pada bagian ini peserta akan diberi tugas untuk berpikir dan menyampaikan ide maupun gagasannya masing-masing berupa Judul yang akan dijadikan sebagai topik karya ilmiah nantinya.

4. Seleksi Judul Karya Ilmiah

Judul Karya ilmiah yang sudah ditulis oleh masingmasing siswa akan diseleksi dan dinilai kelayakannya oleh tim pengabdian. Bagi karya ilmiah yang lulus seleksi akan dilanjutkan ketahap perbaikan tulisan (tahapan ini dilakukan oleh pelajar yang bersangkutan, dibantu dan didampingi oleh salah satu anggota tim pengabdian) agar nantinya dapat menjadi sebuah artikel yang layak untuk dipublikasikan. Proses dari tulisan ini akan terus dipantau oleh tim pengabdian dengan selalu berkoordinasi dengan guru pendamping dari 
masing-masing sekolah sampai menghasilkan sebuah artikel yang layak untuk dipublikasikan.

\section{Praktik Submit Karya Ilmiah}

Setelah semua tahap terselesaikan, maka langkah selanjutnya adalah mempraktikkan bagaimana untuk men-submit karya ilmiah yang sudah ditulis kedalam jurnal atau pun prosiding seminar Nasional. Tahapan ini dipresentasikan dan disajikan pada slide dengan menggunakan proyektor.

Bahan yang digunakan dalam kegiatan pelatihan pembuatan karya ilmiah ini adalah berupa modul (diktat) yang berisikan 5 materi pembahasan sebagai penunjang metode kegiatan yang sudah dijabarkan sebelumnya, antara lain :

I. Pembuatan Karya Ilmiah.

Materi ini berisikan penjelasan mengenai Karya Ilmiah, ciri-ciri karya ilmiah yang baik, jenis-jenis karya ilmiah, Pemilihan Topik hingga Pembuatan outline (Kerangka Tulisan)

2. Pemanfaatan Internet untuk Membuat Tulisan Maupun Penggalian Sumber Pustaka dan Data.

Materi ini berisikan penjelasan bagaimana cara teknik atau cara-cara yang dapat digunakan oleh peneliti untuk pengumpulan data. Teknik dalam menunjuk suatu kata yang abstrak dan tidak diwujudkan dalam benda, tetapi hanya dapat dilihat penggunaannya melalui: angket, wawancara, pengamatan, ujian (tes), dokumentasi, dan lain-lain. Peneliti dapat menggunakan salah satu atau gabungan teknik tergantung dari masalah yang dihadapi atau yang diteliti. Teknik pengumpulan data merupakan langkah yang paling utama dalam proses penelitian, karena tujuan utama dari penelitian adalah mendapatkan data. Teknik pengumpulan data yang diperlukan disini adalah teknik pengumpulan data mana yang paling tepat, sehingga benar-benar didapat data yang valid dan reliable. Sedangkan untuk penggalian sumber pustaka menggunakan media internet pada materi ini dapat menggunakan fasilitas Google Scholar atau dari situs Perpustakaan Nasional RI.

3. Pembuatan Kutipan (Citasi).

Materi ini berisikan penjelasan mengenai bagaimana pembuatan Kutipan (citasi) menggunakan aplikasi Mendeley, termasuk melakukan penginstalan dan registrasi bagi pengguna baru.

4. Laporan Pembuatan penulisan Karya Ilmiah.

Pada pembahasan ini akan diberikan Contoh pembuatan paper (penulisan karya ilmiah) secara keseluruhan dengan Judul : "SPK dalam Pemilihan Siswa Berprestasi Menggunakan Metode Weight Product (WP)"

5. Publikasi Karya Ilmiah.

Materi ini berisikan penjelasan Tips dan Trik Memilih Jurnal Untuk Publikasi dan bagaimana cara untuk submit artikel.

Berikut adalah aktivitas serta jadwal kegiatan PKM Pelatihan penulisan Karya IImiah bagi pelajar SMK di Kabupaten Simalungun (SMK Swasta Anak Bangsa) dan bagi pelajar SMK di Kota Pematangsiantar (SMK Swasta Teladan) yang disajikan dalam Tabel I dan 2:

Tabel I. Pelatihan Penulisan Karya Ilmiah di SMK Swasta Anak Bangsa Kabupaten Simalungun

\begin{tabular}{|c|c|c|c|}
\hline Tanggal & Waktu & Materi & Penyaji \\
\hline \multirow[t]{5}{*}{6 Juli 2019} & $09.30-10.30$ & $\begin{array}{l}\text { Penjelasan tentang } \\
\text { Pembuatan Karya } \\
\text { Ilmiah (I) }\end{array}$ & TIM \\
\hline & $10.30-11.00$ & Pre Test & \\
\hline & $11.00-12.00$ & $\begin{array}{l}\text { Lanjutan Penjelasan } \\
\text { tentang Pembuatan } \\
\text { Karya Ilmiah (I) }\end{array}$ & \\
\hline & $13.30-14.30$ & $\begin{array}{l}\text { Penjelasan dan } \\
\text { pelatihan tentang } \\
\text { Pemanfaatan Internet } \\
\text { untuk Membuat } \\
\text { Tulisan maupun } \\
\text { Penggalian Sumber } \\
\text { Pustaka dan Data (2) }\end{array}$ & \\
\hline & $14.30-16.30$ & $\begin{array}{l}\text { Penjelasan dan } \\
\text { Pelatihan tentang } \\
\text { Pembuatan Kutipan } \\
\text { (Citasi) Tulisan } \\
\text { dengan Menggunakan } \\
\text { Aplikasi Mendeley (3) }\end{array}$ & \\
\hline \multirow[t]{2}{*}{7 Juli 2019} & $08.30-11.30$ & $\begin{array}{l}\text { Penjelasan dan } \\
\text { Pelatihan tentang } \\
\text { Laporan Pembuatan } \\
\text { Penulisan Karya } \\
\text { Ilmiah(4) }\end{array}$ & TIM \\
\hline & $14.30-16.00$ & Penjelasan dan & \\
\hline
\end{tabular}




\begin{tabular}{|c|c|c|c|}
\hline Tanggal & Waktu & Materi & Penyaji \\
\hline & & $\begin{array}{l}\text { Pelatihan tentang } \\
\text { Publikasi Karya IImiah } \\
\text { (5) }\end{array}$ & \\
\hline & $16.00-16.30$ & Post - Test & \\
\hline
\end{tabular}

Tabel 2. Pelatihan Penulisan Karya Ilmiah di SMK Swasta Teladan Kota Pematangsiantar

\begin{tabular}{|c|c|c|c|}
\hline Tanggal & Waktu & Materi & Penyaji \\
\hline \multirow[t]{5}{*}{ I3 Juli 2019} & $09.30-10.30$ & $\begin{array}{l}\text { Penjelasan tentang } \\
\text { Pembuatan Karya IImiah } \\
\text { (I) }\end{array}$ & TIM \\
\hline & $10.30-11.00$ & Pre Test & \\
\hline & $11.00-12.00$ & $\begin{array}{l}\text { Lanjutan Penjelasan } \\
\text { tentang Pembuatan } \\
\text { Karya Ilmiah (I) }\end{array}$ & \\
\hline & $13.30-14.30$ & $\begin{array}{l}\text { Penjelasan dan Pelatihan } \\
\text { tentang Pemanfaatan } \\
\text { Internet untuk Membuat } \\
\text { Tulisan maupun } \\
\text { Penggalian Sumber } \\
\text { Pustaka dan Data (2) }\end{array}$ & \\
\hline & $14.30-16.30$ & $\begin{array}{l}\text { Penjelasan dan Pelatihan } \\
\text { tentang Pembuatan } \\
\text { Kutipan (Citasi) Tulisan } \\
\text { dengan Menggunakan } \\
\text { Aplikasi Mendeley (3) }\end{array}$ & \\
\hline \multirow[t]{3}{*}{ 14 Juli 2019} & $08.30-11.30$ & $\begin{array}{l}\text { Penjelasan dan Pelatihan } \\
\text { tentang Laporan } \\
\text { Pembuatan Penulisan } \\
\text { Karya Ilmiah(4) }\end{array}$ & TIM \\
\hline & $14.30-16.00$ & $\begin{array}{l}\text { Penjelasan dan Pelatihan } \\
\text { tentang Publikasi Karya } \\
\text { Ilmiah (5) }\end{array}$ & \\
\hline & $16.00-16.30$ & Post - Test & \\
\hline
\end{tabular}

\section{HASIL DAN PEMBAHASAN}

Pelatihan pembuatan karya ilmiah bagi siswa di SMK Anak Bangsa Kabupaten Simalungun dan SMK Teladan Kota Pematangsiantar ternyata mendapat respon yang sangat baik dan positif dari peserta kegiatan. Hal ini tampak pada antusiasme peserta dalam mengikuti proses pelatihan. Berikut beberapa gambar berjalannya proses pelatihan.

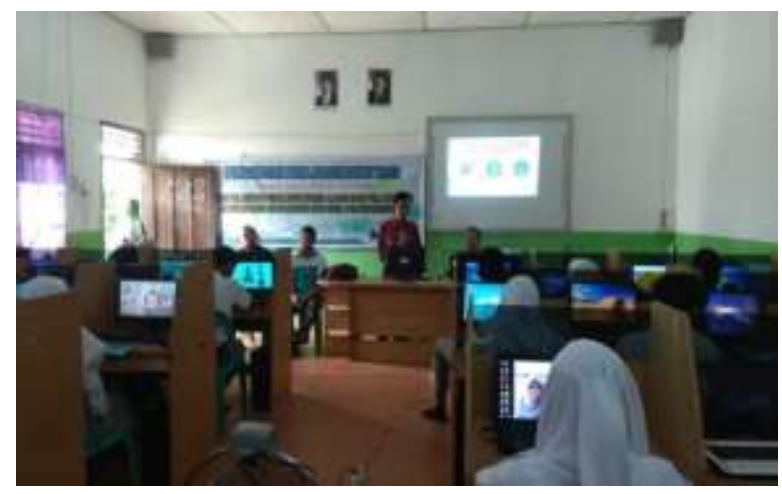

Gambar I. Kata Sambutan Oleh Kepala Sekolah SMK Anak Bangsa Kabupaten Simalungun

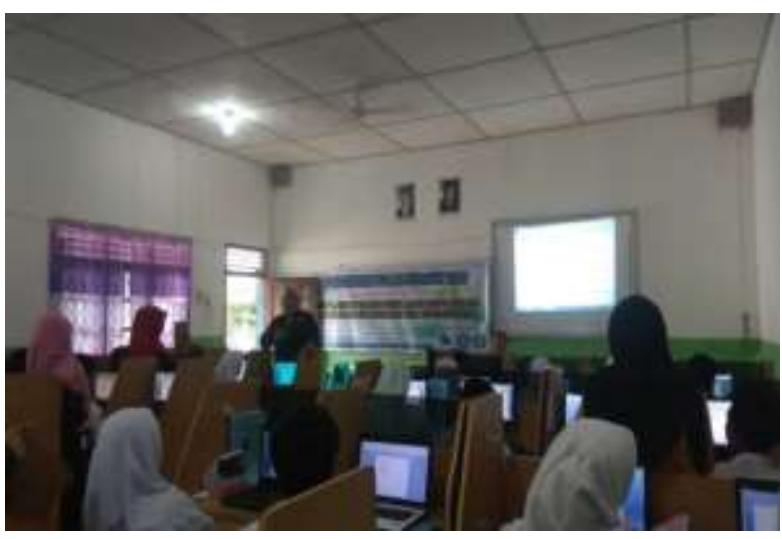

Gambar 2. Kegiatan Pelatihan di SMK Anak Bangsa

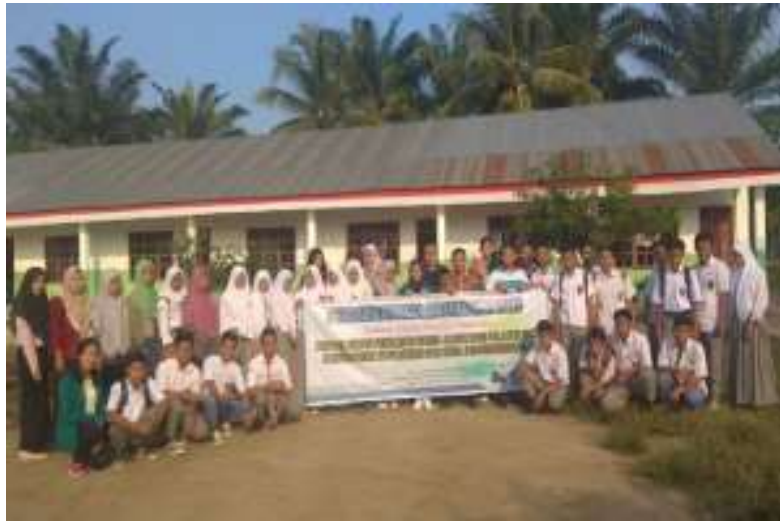

Gambar 3. Foto Bersama Pelajar SMK Anak Bangsa

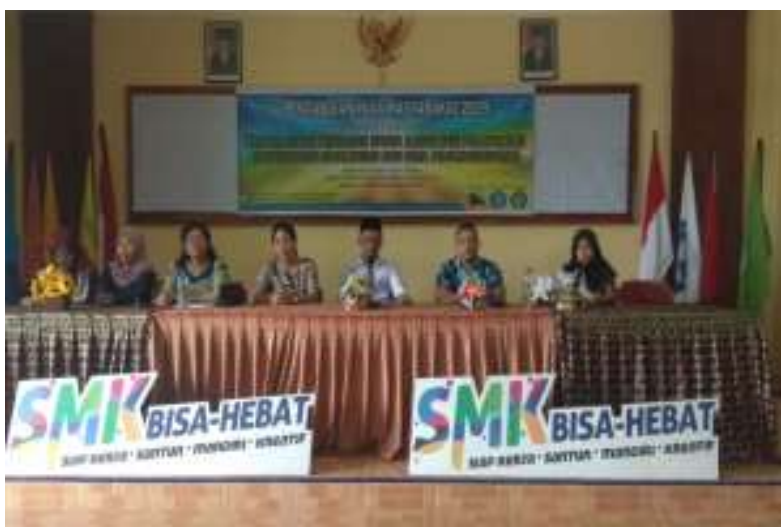

Gambar 4. Kata Sambutan Oleh Kepala Sekolah SMK Teladan Kota Pematangsiantar

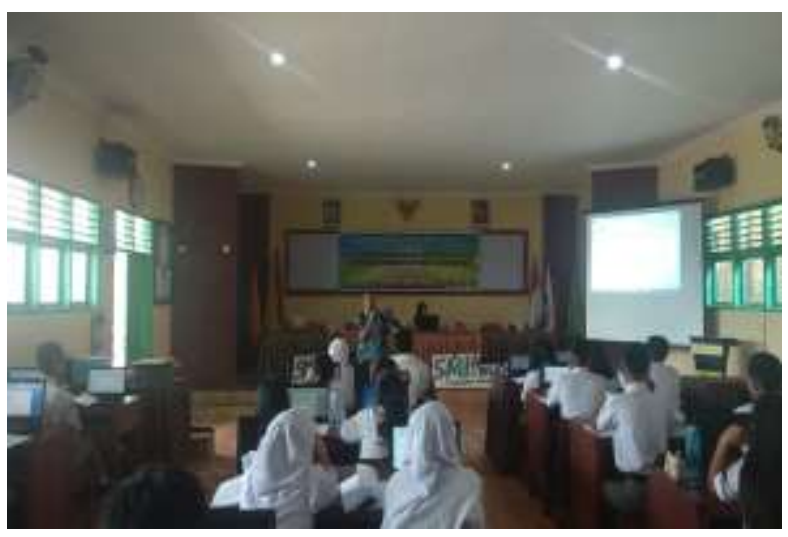

Gambar 5. Kegiatan Pelatihan di SMK Teladan 


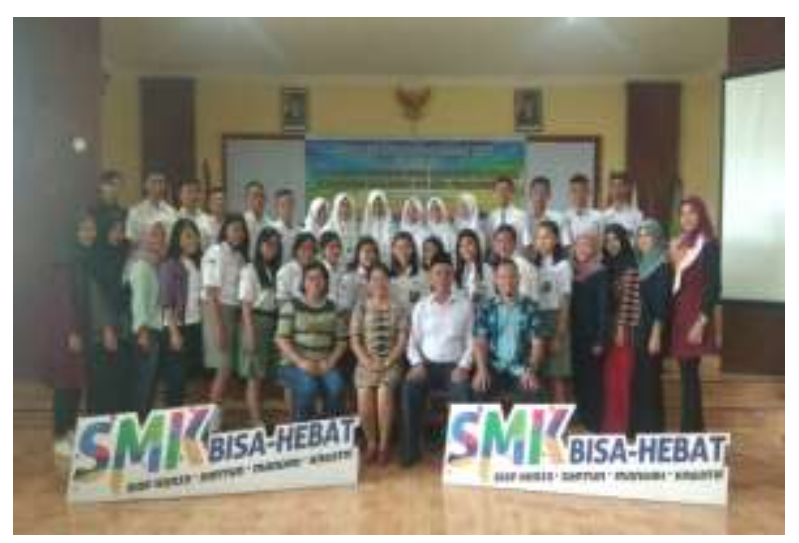

Gambar 6. Foto Bersama Pelajar SMK Teladan

Bagi para siswa yang merupakan peserta pelatihan pembuatan karya ilmiah, kegiatan pelatihan ini dapat meningkatkan pengetahuan dan kemampuan mereka dalam pembuatan karya ilmiah. Hasil Evaluasi terhadap kegiatan Pelatihan Pembuatan Karya Ilmiah di SMK Swasta Anak Bangsa Kabupaten Simalungun dapat dilihat pada tabel 3 berikut.

Tabel 3. Hasil Evaluasi terhadap kegiatan Pelatihan Pembuatan Karya Ilmiah di SMK Swasta Anak Bangsa Kabupaten Simalungun

\begin{tabular}{|c|c|c|c|c|c|c|}
\hline \multirow{3}{*}{ Komponen } & \multicolumn{6}{|c|}{ Hasil Test } \\
\hline & \multicolumn{3}{|c|}{ Pre Test } & \multicolumn{3}{|c|}{ Post Test } \\
\hline & $\begin{array}{l}\text { Jumlah } \\
\text { Benar }\end{array}$ & $\begin{array}{l}\text { Jumlah } \\
\text { Peserta }\end{array}$ & $\%$ & $\begin{array}{l}\text { Jumlah } \\
\text { Benar }\end{array}$ & $\begin{array}{l}\text { Jumlah } \\
\text { Peserta }\end{array}$ & $\%$ \\
\hline \multirow{7}{*}{$\begin{array}{c}\text { Pelatihan } \\
\text { Pembuatan } \\
\text { Karya Ilmiah } \\
\text { dan } \\
\text { Penjelasannya }\end{array}$} & Benar 10 & 0 & $0 \%$ & Benar 10 & 25 & $48 \%$ \\
\hline & Benar 9 & 8 & $15 \%$ & Benar 9 & 14 & $27 \%$ \\
\hline & Benar 8 & 15 & $29 \%$ & Benar 8 & 3 & $6 \%$ \\
\hline & Benar 7 & 10 & $19 \%$ & Benar 7 & 3 & $6 \%$ \\
\hline & Benar 6 & 6 & $12 \%$ & Benar 6 & 7 & $13 \%$ \\
\hline & Benar 5 & 8 & $15 \%$ & Benar 5 & 0 & $0 \%$ \\
\hline & Benar 4 & 5 & $10 \%$ & Benar 4 & 0 & $0 \%$ \\
\hline \multicolumn{2}{|c|}{ Total } & 52 & $100 \%$ & & 52 & $100 \%$ \\
\hline
\end{tabular}

Berdasarkan tabel 3 dapat dijelaskan bahwa dari 52 peserta siswa di SMK Swasta Anak Bangsa, 25 siswa mampu menjawab soal (Post Test) dengan benar sebanyak 10 soal (48\%) dimana sebelumnya hanya mampu menjawab soal (Pre Test) dengan benar 9 soal sebanyak 8 peserta (15\%). Sedangkan Hasil Evaluasi terhadap kegiatan Pelatihan Pembuatan Karya Ilmiah di
SMK Swasta Teladan Kota Pematangsiantar dapat dilihat pada tabel 4 berikut.

Tabel 4. Hasil Evaluasi terhadap kegiatan Pelatihan Pembuatan Karya Ilmiah di SMK Swasta Teladan Kota Pematangsiantar

\begin{tabular}{|c|c|c|c|c|c|c|}
\hline \multirow{3}{*}{ Komponen } & \multicolumn{6}{|c|}{ Hasil Test } \\
\hline & \multicolumn{3}{|c|}{ Pre Test } & \multicolumn{3}{|c|}{ Post Test } \\
\hline & $\begin{array}{l}\text { Jumlah } \\
\text { Benar }\end{array}$ & $\begin{array}{l}\text { Jumlah } \\
\text { Peserta }\end{array}$ & $\%$ & $\begin{array}{l}\text { Jumlah } \\
\text { Benar }\end{array}$ & $\begin{array}{l}\text { Jumlah } \\
\text { Peserta }\end{array}$ & $\%$ \\
\hline \multirow{7}{*}{$\begin{array}{c}\text { Pelatihan } \\
\text { Pembuatan } \\
\text { Karya Ilmiah } \\
\text { dan } \\
\text { Penjelasannya }\end{array}$} & Benar 10 & 0 & $0 \%$ & Benar 10 & 12 & $48 \%$ \\
\hline & Benar 9 & 2 & $8 \%$ & Benar 9 & 6 & $24 \%$ \\
\hline & Benar 8 & 5 & $20 \%$ & Benar 8 & 3 & $12 \%$ \\
\hline & Benar 7 & 3 & $12 \%$ & Benar 7 & 2 & $8 \%$ \\
\hline & Benar 6 & 3 & $12 \%$ & Benar 6 & 2 & $8 \%$ \\
\hline & Benar 5 & 8 & $32 \%$ & Benar 5 & 0 & $0 \%$ \\
\hline & Benar 4 & 4 & $16 \%$ & Benar 4 & 0 & $0 \%$ \\
\hline \multicolumn{2}{|c|}{ Total } & 25 & $100 \%$ & \multicolumn{2}{|c|}{25} & $100 \%$ \\
\hline
\end{tabular}

Berdasarkan tabel 4 dapat dijelaskan bahwa dari 25 peserta siswa di SMK Swasta teladan, 12 siswa mampu menjawab soal (Post Test) dengan benar sebanyak 10 soal (48\%) dimana sebelumnya hanya mampu menjawab soal (Pre Test) dengan benar 9 soal sebanyak 2 peserta (8\%). Hasil Evaluasi secara keseluruhan dari ke 2 Sekolah SMK ini terhadap kegiatan Pelatihan Pembuatan Karya ilmiah dapat dilihat pada table 5 berikut.

Tabel 5. Hasil Evaluasi Keseluruhan terhadap kegiatan Pelatihan Pembuatan Karya IImiah

\begin{tabular}{|c|r|r|r|r|r|r|}
\hline \multirow{4}{*}{ Komponen } & \multicolumn{5}{|c|}{ Hasil Test } \\
\cline { 2 - 7 } & \multicolumn{3}{|c|}{ Pre Test } & \multicolumn{3}{c|}{ Post Test } \\
\cline { 2 - 7 } & $\begin{array}{c}\text { Jumlah } \\
\text { Benar }\end{array}$ & $\begin{array}{c}\text { Jumlah } \\
\text { Peserta }\end{array}$ & $\%$ & $\begin{array}{c}\text { Jumlah } \\
\text { Benar }\end{array}$ & $\begin{array}{c}\text { Jumlah } \\
\text { Peserta }\end{array}$ & $\%$ \\
\hline \multirow{4}{*}{$\begin{array}{c}\text { Pelatihan } \\
\text { Pembuatan } \\
\text { Karya IImiah } \\
\text { dan }\end{array}$} & Benar 10 & 0 & $0 \%$ & Benar 10 & 37 & $48 \%$ \\
\cline { 2 - 7 } & Benar 8 & 20 & $26 \%$ & Benar 8 & 6 & $8 \%$ \\
\cline { 2 - 7 } \begin{tabular}{c} 
Penjelasannya \\
\cline { 2 - 7 }
\end{tabular} & Benar 6 & 13 & $17 \%$ & Benar 7 & 5 & $6 \%$ \\
\cline { 2 - 7 } & Benar 5 & 16 & $21 \%$ & Benar 5 & 0 & $0 \%$ \\
\cline { 2 - 7 } & Benar 4 & 9 & $12 \%$ & Benar 4 & 0 & $0 \%$ \\
\hline
\end{tabular}




\begin{tabular}{|r|r|r|c|r|r|c|}
\hline \multirow{2}{*}{ Komponen } & \multicolumn{5}{|c|}{ Hasil Test } \\
\cline { 2 - 7 } & \multicolumn{3}{|c|}{ Pre Test } & \multicolumn{3}{c|}{ Post Test } \\
\cline { 2 - 7 } & $\begin{array}{c}\text { Jumlah } \\
\text { Benar }\end{array}$ & $\begin{array}{c}\text { Jumlah } \\
\text { Peserta }\end{array}$ & $\%$ & $\begin{array}{c}\text { Jumlah } \\
\text { Benar }\end{array}$ & $\begin{array}{c}\text { Jumlah } \\
\text { Peserta }\end{array}$ & $\%$ \\
\hline \multicolumn{2}{|c|}{ Total } & 77 & $100 \%$ & & 77 & $100 \%$ \\
\hline
\end{tabular}

Berdasarkan tabel 5 dapat dijelaskan bahwa dari sejumlah 77 orang peserta yang terdiri siswa SMK Swasta Anak Bangsa dan SMK Swasta Teladan yang mengerjakan Pre Test dan Post Test wawasan pengetahuan tentang karya ilmiah, dapat diketahui kemajuan pengetahuan peserta test menyangkut materi yang telah disampaikan. Pada sesi Pre Test, peserta test maksimal dapat menjawab 9 soal dengan benar sebanyak 12\% (10 siswa) sementara pada sesi Post Test, peserta mampu menjawab semua soal dengan benar sebanyak 10 soal sebesar $48 \%$ (37 siswa). Hal ini memperlihatkan bahwa yang mereka ketahui tentang karya ilmiah sangat minim sebelum dilaksanakan pelatihan.

\section{KESIMPULAN}

Berdasarkan hasil pelaksanaan kegiatan yang telah dilakukan, dapat ditarik beberapa simpulan bahwa pengetahuan siswa tentang tentang pembuatan karya ilmiah masih kurang memadai sebelum dilaksanakanannya pelatihan. Hal ini ditunjukkan dari hasil pre-test. Penyampaian pengetahuan tentang pembuatan karya ilmiah dapat meningkatkan pengetahuan siswa agar lebih kreatif dalam berpikir untuk menemukan ide dan gagasan yang dapat dijadikan sebagai topik untuk membuat tulisan karya ilmiah. Kegiatan yang dilakukan team dosen dan mahasiswa STIKOM dan AMIK Tunas Bangsa di SMK Anak Bangsa kabupaten Simalungun dan SMK Teladan Pematangsiantar merupakan sebuah kegiatan positif yang bertujuan membekali para siswa tentang pengetahuan dibidang karya ilmiah yang dapat menjadi bekal bagi mereka dalam membuat laporan-laporan kerja praktek maupun sebagai bekal pada saat mereka melanjutkan ke jenjang perkuliahan.

\section{UCAPAN TERIMA KASIH}

Terima kasih yang sebesar-besarnya kami sampaikan kepada Direktorat Riset dan Pengabdian Masyarakat, Direktorat Jenderal Penguatan Riset dan Pengembangan Kementerian Riset, Teknologi, dan Pendidikan Tinggi atas pendanaan yang diberikan sesuai dengan Kontrak Penugasan Pelaksanaan Program Pengabdian kepada Masyarakat Nomor: T/209/LI.3.I/PT.0I.03/20I9

\section{REFERENSI}

Casmudi, C., \& Ryan Angga Pratama. (2019). Pelatihan dan Pendampingan Penulisan Karya Ilmiah Remaja bagi Siswa/i SMA/Sederajat di Kecamatan Muara Jawa, Kabupaten Kutai Kartanegara. Abdimas Universal, I(I), I-5. https://doi.org/I0.36277/abdimasuniversal.vlil.I3

Kumalasari, D., Rokhman, M. N., \& Zulkarnain. (20I5). Pelatihan dan Pendampingan Penulisan Karya IImiah Sejarah Berwawasan Pendidikan Karakter.

Marlene, N., Dwijayanti, R., Patrikha, F. D., \& Parjono, P. (2017). Pelatihan Penulisan Karya Tulis Ilmiah (KTI) bagi Guru SMA Swasta di Sidoarjo. Jurnal ABDI, 2(2), 45-50. Retrieved from https://journal.unesa.ac.id/index.php/abdi/article/v iew/863

S. Sumartini, Mulyani, M., \& Nugroho, B. A. (2019). Workshop Penulisan Karya IImiah bagi Guru Sekolah Dasar di Kabupaten Demak. Jurnal Puruhita, I(I), 54-59.

Syamsul Alam. (20I5). Penulisan Artikel IImiah Untuk Publikasi Ilmiah Melalui Jurnal. Jurnal E-Buletin, (April), I-19.

Wanto, A., Suhendro, D., \& Windarto, A. P. (2018). Pelatihan dan Bimbingan dalam Pemanfaatan Internet yang Baik dan Aman bagi Pelajar SMK Anak Bangsa Desa Bandar Siantar Kabupaten Simalungun. E-DIMAS: Jurnal Pengabdian Kepada Masyarakat, 9(2), I49-I57. 